Informatika i sistemy upravleniya. - 2017. - No. 3(53). - P. 17-23.

Bobkov V.A. (bobkov@dvo.ru)

Institute of Automation and Control Processes

\title{
VISUAL ODOMETRY ON A LONG FEATURES TRACKING
}

The article suggests visual odometry algorithm based on long tracking features from stereo images for autonomous underwater vehicle. There were given results of the experiments with simulated and real data.

Keywords: autonomous robot, trajectory, stereo images, tracking feature points, navigation.

DOI: $10.22250 /$ isu.2017.53.17-23

For citation:

Bobkov V.A. VISUAL ODOMETRY ON A LONG FEATURES TRACKING // Informatika i sistemy upravleniya. - 2017. - No. 3(53). - P. 17-23. 